\title{
Relapse among Drug Addicts in East Coast Malaysia: A Qualitative Study of Risk Factors
}

Muhammad Asyraf Che Amat, Jamaludin Ahmad, Othman Jailani, Wan Marzuki Wan Jaafar, Zeinab Zaremohzzabieh

To Link this Article: http://dx.doi.org/10.6007/IJARBSS/v10-i12/8337

DOI:10.6007/IJARBSS/v10-i12/8337

Received: 10 October 2020, Revised: 12 November 2020, Accepted: 29 November 2020

Published Online: 18 December 2020

In-Text Citation: (Amat et al., 2020)

To Cite this Article: Amat, M. A. C., Ahmad, J., Jailani, O., Jaafar, W. M. W., \& Zaremohzzabieh, Z. (2020). Relapse among Drug Addicts in East Coast Malaysia: A Qualitative Study of Risk Factors. International Journal of Academic Research in Business and Social Sciences, 10(12), 432-447.

Copyright: (c) 2020 The Author(s)

Published by Human Resource Management Academic Research Society (www.hrmars.com)

This article is published under the Creative Commons Attribution (CC BY 4.0) license. Anyone may reproduce, distribute, translate and create derivative works of this article (for both commercial and non-commercial purposes), subject to full attribution to the original publication and authors. The full terms of this license may be seen at: $\underline{\text { http://creativecommons.org/licences/by/4.0/legalcode }}$

Vol. 10, No. 12, 2020, Pg. $432-447$

Full Terms \& Conditions of access and use can be found at http://hrmars.com/index.php/pages/detail/publication-ethics 


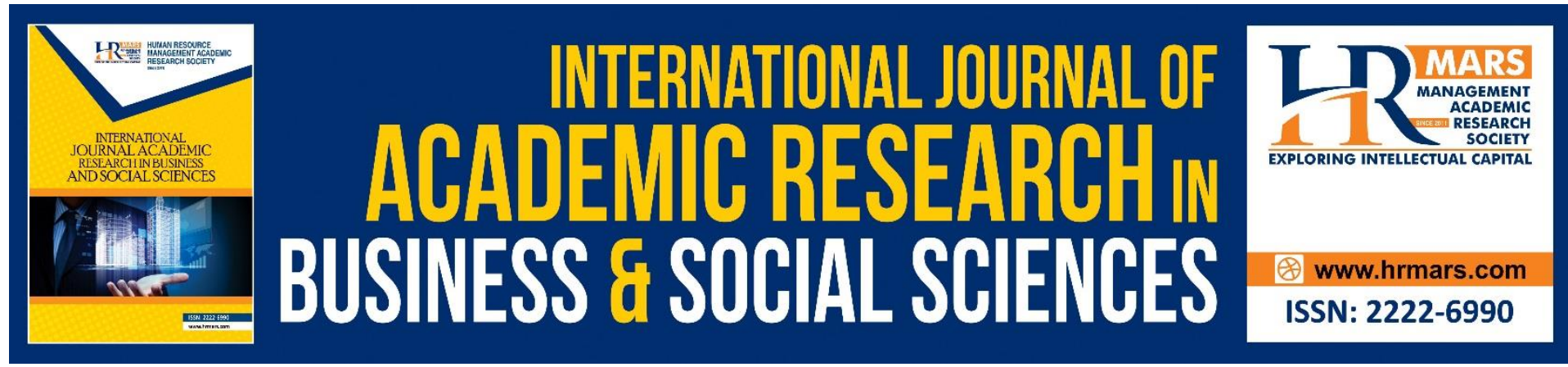

\title{
Relapse among Drug Addicts in East Coast Malaysia: A Qualitative Study of Risk Factors
}

\author{
Muhammad Asyraf Che Amat, Jamaludin Ahmad, Othman \\ Jailani, Wan Marzuki Wan Jaafar, Zeinab Zaremohzzabieh
}

Faculty of Educational Studies, Universiti Putra Malaysia, Serdang 43400, Selangor, Malaysia

Email:mhdasyraf@upm.edu.my,mal@upm.edu.my, obj@upm.edu.my, wanmarzuki@upm.edu.my,z_zienab@upm.edu.my

\begin{abstract}
This study aimed to identify the risk factors of relapse among drug addicts who were repeatedly admitted to the Narcotics Recovery and Addiction Centre (PUSPEN). This qualitative study utilized an interview method to gain a deeper understanding of the factors that contribute to the relapse phenomenon. The study sample comprised of seven relapsed drug addicts who were admitted to the centre more than once. The interview sessions were conducted at two PUSPEN centers in the east coast of Malaysia, which are PUSPEN Jeli and Bachok. These centers cater for both male and female drug addicts. The current study found that the risk factors of relapse among the drug addicts are internal factors. The themes that emerged in these risk factors include lack of willpower, boredom, frustration, lack of religious knowledge and practices, anger, and resentment. Apart from that, other risk factors are such as lack of family support, income factor (scarce income and surplus income), the influence from old friends, rejection from the community, social media influence, and no place to go after being released are also contributing factors to the reoccurrence of relapse. The findings of this study provide practical implications for the drug treatment and rehabilitation in Malaysia.
\end{abstract}

Keywords: Drug Addicts, Relapse, Relapsed Drug Addicts, Addiction Counselling, Rehabilitation Counselling.

\section{Introduction}

The issue related to drug abuse is not foreign to Malaysia. As an attestation to this claim, in 1983 the Malaysian government had stated that drug abuse is not only a social problem, but also a threat to national security (Shariff et al., 2019). Drug abuse is regarded as a national threat as it generates massive adverse effects on social, political, and economy. Resolving drug issues requires demanding efforts from the government. The complication is nonetheless aggravated by the phenomenon of drug addiction relapse. Addiction relapse is one of the difficult challenges in the treatment and rehabilitation of drug addicts. Treatment and rehabilitation programs had been implemented in Malaysia since 1975 to free the addicts from the manacles of drugs (Chie et al., 2015). However, the numerical evidence still indicates a skyrocketed of relapse cases. Despite the alarming rate of relapse cases, the number of drug 
addicts admitted to the Narcotics Recovery and Addiction Centre (PUSPEN) is also increasing every year (Lian \& Chu, 2013). This phenomenon has raised questions among the Nongovernment Organizations (NGOs), community, and even the government, specifically about the contributing factors.

According to Emrick and Beresford (2016), the failure of former drug addicts to change their way of life is not yet fully understood because many risk factors lead to relapse or none that helps them to maintain a drug-free life. Parallel to this statement, a study by Ibrahim et al. $(2008 ; 2009)$ found that even the former drug addicts who received a good family support bring no avail to prevent them from being relapsed. Besides, the study also shows that the majority of drug addicts feel uncomfortable sharing their problems with their families. Chie et al. (2015) found that self-esteem is the main factor that contributes to the inclination towards addiction relapse. Their study concludes that a low self-esteem among drug addicts contributes to relapse cases Ibrahim et al. (2011). Most drug addicts said that they did not have enough willpower to undergo and endure a strenuous attempt to break the addiction cycle. Liu et al. (2017) found that siblings' influence is associated with drug abuse where older siblings tend to influence the younger ones. The inclination towards drug abuse among siblings is greater if there is any family member also committed to drug abuse.

Many studies regarding this matter have been carried out (Khasmohammadi, 2020). However, Malaysia is still lagging. Furthermore, insofar, there is no study conducted in the east coast of Malaysia. This research was, therefore, carried out to determine the risk factors for the relapse of drug addiction in the east coast of Malaysia. This study was based on the real-life experiences of drug addicts. The conceptualization of their experiences is essential to acquire a deeper understanding of this adverse phenomenon. This study intended to explore the reasons of why drug addicts in the east cost of Malaysia still relapse, despite having undergone treatment many times.

\section{Literature Review \\ Relapse Among Drug Addicts}

Drug addiction is referred to as a relapsing disorder since it is normal for people in treatment to relapse (Rahman et al., 2016). Repeated use of drugs can trigger brain changes that can influence the self-control and ability of an addicted individual to resist cravings (Song et al., 2019). Prevention of opioid relapse is an important aspect of the healing process and for several years, individuals remain at an elevated risk. The definition of drug relapse is evolving, thereby complicating efforts to explain it. Researchers debate whether drug relapse is a process or an outcome in and of itself (e.g., Dong et al., 2017). The concept of drug relapse is changing, making attempts to describe it more difficult. Researchers are debating whether opioid relapse is in and of itself a mechanism or a result. The roots of the concept of drug relapse come from a medical paradigm that looks at addiction as a disease; after a period of rehabilitation, a patient returns to a state of illness. As the idea progressed, it came to encapsulate the pathway that causes people to return to their substance addiction, while in recovery.

Drug abuse is generally thought of as a "chronically relapsing disorder" (Witkiewitz \& Marlatt, 2004), with high rates of substance abuse following treatment for both young people and adults. Studies report that in the six months following a community- or hospital-based opioid or alcohol recovery episode, about two-thirds and four-fifths of both adults and teenagers begin to use the substance again (Brown et al., 2001; Williams \& Chang, 2000). The characterization of relapse "determinants", or contextual aspects of conditions, in which 
adults and teenagers appear to use after they have been treated for drug or alcohol problems, has been a major focus of research investigating the addiction relapse method.

It is important to understand the risk factors and causes that usually contribute to relapse in order to prevent relapse. To avoid the possible risk of relapse during or after treatment, knowing these risk factors will benefit them. Sometimes, a catalyst that causes someone to begin thinking about relapsing or induces a desire for a drug that was previously used will precede relapse. These causes can be difficult to detect and, if they lead to relapse, can fully interrupt a recovery.

Two key forms of triggers can start the process of relapse for anyone; external triggers and internal triggers. External drug addiction triggers are triggers that come from their world, such as objects, individuals, or locations they come into contact with. External stimuli, once understood, are easier to manage. Internal relapse causes for drug abuse are stimuli that come from the inside, usually through one's emotional condition or method of thinking. It may take less effort to prevent these stimuli when they are identified. It may also be more likely that these stimuli arise subconsciously, making them important to identify and prevent. Both kinds of causes face specific problems that can derail a phase of recovery (Asensio et al., 2020). To prevent future relapse, it is important to understand how these causes affect the addicts. It is difficult for a large number of individuals to deal with drug abuse to avoid relapse causes. Another problem is the detrimental side effects of relapsing when enrolling in services for drug and alcohol treatment. Drug and alcohol dependence after abstinence has increased the likelihood of a person being overdosed in recent experiences (Sabouripour \& Roslan, 2015; Stein et al., 2017).

\section{External Factors}

By associating with other memories, our brain stores memories. A location will also trigger a memory of a case, or smelling something, such as a specific cologne will trigger a beloved relative's memory. The way the brain connects memories is through a powerful tool used to help the addicts remember crucial information, but it can also influence their process of recovery. Their brain connects the act of using a drug with locations where they used the drug, the individuals they used the drug with or purchased from, and other substance userelated products. It allows their brain to think of the drug they used to take when they are exposed to certain objects or individuals, which may trigger cravings for the drug. This can also contribute, beyond cravings, to a nostalgia for the world or lifestyle they had left, which does not offer the same reminder for the reasons they initially sought rehabilitation. Whenever possible, avoid external triggers and get rid of any item, which can lead to a cause of relapse. Ending certain past friendships can entail avoiding external causes (van Delden, 2017). Realize that these partnerships are detrimental to them and make sure that the relationship is fully cut off; it is much less likely that a half-way end to a bad relationship will work.

\section{Internal Factors}

Usually, internal relapse causes are linked to feelings or thinking processes that may cause a drug or alcohol craving. It can be harder to stop these stimuli since they are sometimes subconscious (Chen et al., 2019). Tackling these triggers successfully involves the understanding of what kind of triggers to watch for and being conscious of their emotions and thoughts. Some common internal causes for relapse include: 
Everyone will have multiple internal triggers, but they will be better prepared to prevent or fix their internal triggers by identifying some of the common ones. If they are beginning to consider relapse, they may find that perhaps subconsciously, they are exposing themselves to potential causes. They can quickly reach out to someone they can trust and who is supportive of their rehabilitation if they are in high-risk circumstances that might cause a relapse. Talking about the trigger and enlisting the help of someone else will provide them with the requisite support and assistance to resolve the trigger and remain sober (Stewart et al., 2019). If they are exposed to a possible stimulus, and if they fight the temptation to relapse, the cravings can pass within a few hours. It would be very helpful in preventing relapse to have a strategy to get through periods when their cravings are caused.

\section{Methods}

\section{Research Approach}

This study utilized a qualitative method to gain a profound understanding of the reason for their addiction relapse. The qualitative approach allows the researcher to get an in-depth understanding especially from the perspective of respondents or informants (Richards, 2005; Creswell \& Creswell, 2017).

\section{Setting}

This study was conducted at the Narcotics Recovery and Addiction Centre (PUSPEN). PUSPEN is a place where drug addicts receive rehabilitation to cease their addiction and return to their normal life. As for the data collection, this study was conducted in the east coast of Malaysia at PUSPEN Jeli and PUSPEN Bachok, Kelantan. The rationale behind the selection of PUSPEN Jeli is because it has relapsed addicts who have been in and out the center many times. Bachok PUSPEN was chosen because it housed female addicts undergoing rehabilitation.

\section{Sampling}

The sample comprised of individuals who can provide information on the issue being studied (Creswell \& Creswell, 2017; Etikan \& Bala, 2017). This study employed purposive sampling. According to Goodson and Sikes (2001), purposive sampling is used when the researcher wants to gain a deeper understanding regarding the issue from the sample and it enables the researcher to obtain as much information as possible.

The number of informants for this study is not restricted by the conditions and rules, however, the determination was based on the objective of the study, time suitability, research questions, as well as the validity and reliability of the study. Based on those criteria, seven respondents were selected by using a purposive sampling. The age of the respondents was between 20 to 55 years old and represent multiple races and genders. The rationale behind the multiple representations is so that the sample was not confined to a specific group. 15 respondents for most qualitative interview studies works very well (Baharudin et al., 2011; Crouch \& McKenzie, 2006; Rami et al., 2018). In this study, the information is obtained from seven selected respondents as eight of them were eliminated due to missed responses regarding drug abuse relapse.

\section{Data Collection Method}

This study used the interview method to explore risk factors that lead to drug relapse. According to Merriam and Grenier (2019), the interview method is the most used data 
collection method for a qualitative study. The interview is mainly used to obtain data about facts, feelings, beliefs, and other aspects related to the research. The interview sessions for this study were conducted using a semi-structured interview. Galletta (2013) states that the questions in the semi-structured interview were organized and scheduled beforehand, however, the questions may be modified per context and circumstances. A semi-structured interview stands between a structured interview and an unstructured interview in terms of its flexibility. The respondents were also given the flexibility to answer the questions. The advantage of using this method is that the researcher could obtain more circumstantial and comprehensive data. The collected data were then capsulized to determine the recurring themes and the relapsing factors were then analyzed via categorization. Those themes were formed from the transcription of interview scripts with the informants. The data analysis for this study did not involve specifics as in quantitative studies.

\section{Data Analysis}

Researchers increase reliability in qualitative research when bias is overcome and can be reflected in data interpretation by an external audit. Further assurance of reliability is demonstrated by the use of high quality computerized data analysis software by strictly following the procedures of the program (Merriam \& Tisdell, 2015; Darwish \& Abdeldayem, 2019). The ATLAS.ti software (version 8.0) was used to analyse the collected data. The use of this software had allowed the researcher to compile, analyse and make the connection between the themes.

\section{Results}

\section{Background of Informants}

Seven informants detained in the PUSPEN Jeli and Bachok, were 28 to 55 years old relapsed addicts. Those seven respondents comprised of three males and four females; three Malays, two Chinese, and two Indians. Table 1 below demonstrates the background of the respondents. 
Table 1

Background of Informants

\begin{tabular}{|c|c|c|c|c|c|c|c|}
\hline Informant & 1 & 2 & 3 & 4 & 5 & 6 & 7 \\
\hline Gender & Female & Male & Female & Male & Female & Male & Female \\
\hline Race & Malay & Malay & Indian & Chinese & Chinese & Indian & Malay \\
\hline Age & 55 & 29 & 39 & 42 & 40 & 47 & 28 \\
\hline Religion & Islam & Islam & Islam & None & Christian & Islam & Islam \\
\hline $\begin{array}{l}\text { Education } \\
\text { Background }\end{array}$ & None & UPSR & Form 1 & SRP & Standard 5 & SRP & Form 4 \\
\hline Marital Status & Widow & Single & Married & Single & Single & Widower & Widow \\
\hline $\begin{array}{l}\text { Previous } \\
\text { Occupation }\end{array}$ & Drug seller & $\begin{array}{l}\text { Lorry } \\
\text { driver }\end{array}$ & Factory & $\begin{array}{l}\text { Security } \\
\text { Guard }\end{array}$ & $\begin{array}{l}\text { Promoter at } \\
\text { JUSCO }\end{array}$ & Car Wash & $\begin{array}{l}\text { Factory } \\
\text { worker }\end{array}$ \\
\hline Salary & Not fixed & $\begin{array}{l}\text { RM } \\
2500.00\end{array}$ & RM 900.00 & $\begin{array}{l}\text { RM } \\
1200.00\end{array}$ & RM 1000.00 & $\begin{array}{l}\text { RM } 30.00 \\
\text { per day }\end{array}$ & RM 800.00 \\
\hline Frequency & & & & & & & \\
\hline $\begin{array}{l}\text { Detained in } \\
\text { PUSPEN }\end{array}$ & 3 times & 2 times & 3 times & 3 times & 2 times & 3 times & 3 times \\
\hline $\begin{array}{l}\text { Duration of } \\
\text { Involvement } \\
\text { in Drug Abuse }\end{array}$ & 34 years & 6 year & 22 years & 23 years & 6 years & 32 years & 9 years \\
\hline
\end{tabular}

\section{Research Question}

After the analysis of the transcripts was completed, eleven themes were identified. Different answers with similar meanings were categorized into one theme. The eleven themes were summed up as a sub-theme under two main themes, which are risk factors.

\section{Main Theme: Risk Factors}

The themes identified from internal factors are lack of willpower, frustration, boredom, lack of religious knowledge and practices, anger, and resentment. The results show that six informants, including females and males from different racial backgrounds were involved with this factor. 
Table 2

Emerged themes and sub-themes.

\begin{tabular}{|c|c|c|}
\hline No. & Themes & Sub-themes \\
\hline 1 & Lack of willpower & - \\
\hline 2 & Boredom & - \\
\hline 3 & Frustration & - \\
\hline 4 & Lack of religious knowledge and practice & - \\
\hline 5 & Anger and resentment & - \\
\hline 6 & Family factor & $\begin{array}{l}\text { - Lack of love in the family } \\
\text { - Feeling alienated in the } \\
\text { family } \\
\text { - Feeling alienated in the } \\
\text { family }\end{array}$ \\
\hline 7 & Income factor & $\begin{array}{l}\text { - No source of income } \\
\text { - Income surpluses }\end{array}$ \\
\hline 8 & Influence of old friends & - \\
\hline 9 & Rejection from the community & - \\
\hline 10 & Influence of the mass media & - \\
\hline 11 & $\begin{array}{l}\text { No place to go after being released from the rehab } \\
\text { center }\end{array}$ & - \\
\hline
\end{tabular}

\section{Theme One: Lack of Willpower}

Most of the informants stated that it was difficult for them to put an end to the addiction as they were lacking the willpower to persevere the attempt. In the end, they kept going back to their old habit of drug abuse. This is reflected in the statement by Informant 1:

"I still can contain myself without drugs, but not to the point where I feel irritated or annoyed. With a slight emotional disturbance from remembering the previous experience, I could cry and go back to the drug. I could not contain myself when I remember my previous experience, I will retake the drug."

Informant 6 was of the opinion that relapsed addicts cannot blame others for what had befallen them. The root cause of the relapse is in themselves. Informant 6 stated that:

"We go back to the drug just as we knew there is a hole beneath our feet, yet we deliberately step in there to inflict pain upon ourselves."

\section{Theme Two: Boredom}

Boredom is also one of the factors that contributed to the relapse among the drug addicts. They had an abundance of free time. Hence, in their free time, they started to remember the debauchery they committed and started to miss the drug dissipation. Informant 4 stated that:

"...We were bored, and we had no idea how to fill the void within ourselves. It stressed us out, then we went back to drugs."

\section{Theme Three: Frustration}

Frustration is one of the reasons for a drug relapse. They wanted to eliminate the frustration that weighed them down, hence they resorted to substances, such as alcoholic beverages and drugs. They would first resort to the alcoholic beverage. After that, they 
started to visualize substances that have a stronger soothing effect on their mind. This can be seen from the Informant 6 's statement:

"I tried to stop by abandoning the drugs, I prayed, I did this and that, it seemed I succeeded at first, yet the misery I felt intensified when I was tested with divorce, people close to me passed away and disastrous events befell them."

A statement from Informant 2 attests this sub-theme:

"...When I felt stressed out, frustrated, I got a headache, then I consumed alcoholic drinks daily, that is how I was stucked with drugs again."

\section{Theme Four: Lack of Religious Knowledge and Practice}

Religion plays an important role in a person's life. Religion teaches humans to be virtuous and have a good moral conduct. This study found that poor religious knowledge is also a factor in a drug relapse and makes it easier for the person to get trapped in the same circle. This can be seen in the statement of Informant 4:

"I was not so religious before, I didn't know my religion. I believe religious men will have faith and it would guide them to be good man. Any religion does not allow their followers to be a drug addict."

\section{Theme Five: Anger and Resentment}

Anger and resentment have been identified as a personal sub-factor that lead them back to the drugs. Informant 5 said,

"I had no idea how to drive a car, then I called the police to take me to the hospital, the police refused to do so, then I relapsed, I searched for ice. Back then, I felt like dying if I did not consume drugs, I felt uneasy."

This statement is also supported by Informant 2 who concurred that anger and resentment are the reasons for relapsing, of which he said,

"...Even after I was released from the center, I had a somewhat dissatisfied feeling because back then after I was caught by the police, I was forced to be here. It was not because I wanted to. I still bear the resentment, thus when I am free from this place, I will retake the drug."

\section{Theme Six: Family Factor}

A fragile and vulnerable family institution is one of the factors that give rise to the relapse case. Children from a broken family tend to be abandoned and are susceptible to destructive behaviors.

Sub-theme: Lack of Love in the Family. Lack of love in the family contributes to the drug relapse among drug addicts. According to Informant 1, she was thrown out from her family's home when she was 11 years old, and she subsequently got married and bore a child at the age of 12 . The refusal of her family to accept her again led her and her husband to addiction relapse, as reflected in her statement:

"My family disowned me. No matter what I did, they will not accept me...My family did this to me since I was little. I was sad and resentful. Until now, I cannot accept this reality. All my siblings have the chance of going to school, yet I own nothing. I was treated unjustly, but I don't care anymore. I went back there 14 years later, they still 
could not accept me, not even when I brought along my husband and kids with me. Then I thought, I don't want to go back there ever again. Enough. 15 years later, I got divorced."

Sub-theme: Feeling Alienated in the Family. The conflict between parents and teenagers could contribute to misbehavior among teenagers. The inability to adapt and cope with the conflicts would raise a social issue (Jaafar, 2002). This can be seen from Informant 3's statement:

"I want my family to be comfortable with me. Sometimes, when I went back home, my mom gave me a look like I'm her stepchild. I think I am a stepchild in my family because my other siblings were treated fairly by my parents. Why did my parents look at me with such a look? Thus, I should be a drug addict. It will make it easier for me to die."

\section{Theme Seven: Income Factor}

Sub-theme: No source of income. Scarce income or surplus income could also lead to the issue of relapse. Age factor and the difficulty to secure a job lead drug addicts to resort to a short cut by selling drugs to make a living. Once they committed to the world of drugs, they will be shackled by it and it will be difficult for them to cease the addiction. Informant 1 attested this when she said:

"...I took drugs again because I was desperate and my life was difficult. I did not have enough money even though I have a job as I had rented a room with a rate of RM 24 per day. I had no idea what else to do. All my friends are drug addicts. I borrowed money from them, then I used it as capital for drug business so that I have money to make a living."

Sub-theme: Income surpluses. Having lots of money is also a factor that causes relapse. Most of the informants did not know what to do with the extra money they had, and at that point, they began to remember their old memories and went back to doing things like drinking alcohol, and they eventually got trapped in drugs. This condition is reflected in Informant 6's statement:

"If you have a lot of money, you don't know what to do. Other people know how to save that money, but I don't know how to keep it. Since my childhood, if I had money, I would prefer to spend it."

\section{Theme Eight: Influence of Old Friends}

The influence of old friends also plays a role in causing the drug addicts to relapse. Edwards (2001) found that individuals are susceptible to peer pressure and will follow their lifestyle as a requirement for group acceptance. According to Informant 4, most of his old friends were drug addicts and it was among the factors that led him to relapse. He said:

"I have been taking drugs for a long time, my friends were mostly addicts too. If I'm still involved with them, over time, l'll take it back."

Informant 2 also said the same thing. The feeling of friendship with old friends permeates in the drug addicts when taking drugs together. According to him: 
"When I felt bored, and do nothing, I started meeting my old friends. At first, it was just a chit chat, but it was no fun, then together we took drugs, and the feeling of friendship comes."

\section{Theme Nine: Rejection from the Community}

According to Informant 2, the attitude of the local community who often sees the former addicts like a villain was challenging to them. He said:

"usually when I was released from the rehab center, I always went for prayers at the mosque. Most of my villagers said I just pretended to be good."

He added that if the crime occurred in the village, such as the mosque's money was stolen, people would start looking at him as if he was the one who did it. According to Informant 2:

"When the mosque's money bank was broken, people were going to accuse me, even though I was trying to be a good member of the mosque, when I was accused, it made me shy to go to the mosque again because I felt like an evil in their eyes."

\section{Theme Ten: Influence of the Mass Media}

Another factor that the researcher found in this research is the influence of mass media. Stories that appear in mass media, such as television can sometimes cause an addict to recall the memories that haunted them. This can be seen in the statement of Informant 6:

"The stories in the cinema have given me a lot of memories my past, a lot of heartaches and I began to think about taking the drug back."

\section{Theme Eleven: No Place to Go After Being Released From the Rehab Centre}

When released from the rehab center, some addicts did not know where they wanted to go. Some of them did not want to go back to their families because they did not want to burden them anymore. Furthermore, the feeling they had when often being associated with negative things was hard to bear. Since they had nowhere else to go, they finally returned to their old friends whom to them understand their souls better. Informant 3 stated:

"I don't know where to go when released from this center, my sister is married, she has children, my brother and sister in law also have kids, and they don't smoke, their kids are well-educated. When I went and lived with them, sometimes my siblings also said to their kids, don't go with him, that is a bad guy, he takes drugs."

\section{Discussion}

The findings of this study have successfully answered the research questions, which was to identify the main risk factors of why the drug addicts relapse. From the results, eleven factors contribute to the relapse phenomenon. Internal factors, which are lack of willpower, frustration, boredom, lack of religious knowledge and practice, anger and resentment, and external factors, which are lack of family support, income factor (scarce income and surplus income), rejection from the community, influence from old friends, influence from the mass media and no place to go after being released from the rehab center have been identified as major contributors to the relapse phenomenon.

Internal factor is identified as the main factor that leads to the relapse phenomenon among drug addicts. The result shows that most participants have a lack of willpower, which caused them to relapse. This finding is consistent with the work of Ibrahim and Kumar (2009) 
who found that the main cause for women's involvement in drug abuse is due to a low willpower and a low self-esteem. This finding is also in line with the self-efficacy theory by Bandura (1997), which states that self-esteem is an important factor in a behavior change because it is the initial determination to do something despite the obstacles they will face. That is why most current initiatives have often placed importance on the improvement of self-esteem in their clients (Habibi et al., 2016). We recommend that the staff of anti-drug programs of different modalities review the factors in their programs that aim to improve self-esteem and review their effectiveness. Although overseas experience in improving selfesteem can be a useful source of reference for improvement, particularly those built according to the well-known model for the prevention of relapse, the local expertise service providers should also come together for a mutual sharing in this regard.

The findings also show that frustration puts drug addicts at a greater risk for using drugs and becoming addicted. There are many possible reasons for this increased risk of addiction. One is that some people get frustrated to take drugs because the drugs make them feel better, or they believe the drug helps them deal with their problems. Also, frustration affects the same brain circuits and chemicals as drugs do when abused. The overlapping effects of a mental disorder and a drug may increase the risk of addiction (Volkow et al., 2012). In this essence, some people will easily push through their normal day to day feelings. However, as small as these things maybe for some people, these are relapse triggers for people in drug addiction recovery.

Lack of family support is the second major factor identified. The result shows that the absence of open interaction between the participants and their family members had contributed to the tendency of relapse among the drug addicts. According to Taib and Khairi (2000), one of the reasons for addicts' discomfort in communicating their problems with family members is because of the existing communication barriers and ineffective interactions among family members. This finding is parallel with the works by Merikangas and Steven (2005) and Ibrahim et al. (2008) who found that the lack of open interaction and a loose communication among family members would lead to a depression, which might eventually lead to a drug addiction.

Furthermore, the findings highlight that a safe and supportive family environment has a significant impact on a person's risk for drug abuse and addiction (Mericle et al., 2015). Drug addicts are at a greater risk if they live in chaotic homes where there is little parental or adult supervision (Fraser \& Moore, 2008). This type of home environment can be the result of parents or older family members who suffer from a mental disorder, engage in criminal behavior, or abuse drugs or alcohol. On the other hand, a nurturing home environment as well as clear rules of conduct at home, can be protective factors that prevent the potential for drug abuse.

The factors of income and lack of religious knowledge and practice are also the reasons why drug addicts can be trapped in this vicious cycle. Income surpluses caused them to start thinking wildly, thus intriguing them to spend money on drugs. The old memories of how fun taking drugs was, continue playing in their mind. Moreover, having money in their hand had caused them to fall back into relapse. A scarce income was also the cause, of which insufficient funds led them to return to their old job of drug trafficking. Recent studies by Brown University have proven that "exposure to stress is associated with drug addiction in humans and can induce relapse and craving (Sinha et al., 2011, p. 71)." In other words, stress is also a critical factor in drug and alcohol relapse. In many cases, addiction relapse rates are much higher for individuals dealing with stress. Besides, we may use religious beliefs or rituals to 
provide the mental and emotional support that is important for abstinence. Some programs can also organize small businesses, such as courier and moving services, for treated clients to engage in paid jobs during the rehabilitation period.

The National Anti-Drug Agency (2015), in a study on the major factors that cause teenagers to be involved in drug abuse, found that the peer influence factor was at the top. Mahoney and Stattin (2000) found that old friends' influence also play a significant role with a persons' involvement in drug addiction. Those findings support the finding in this study that old friends' influence factor also contributes to the relapse phenomenon among drug addicts. Most participants mentioned how hard for them to make new friends. Such is because of their addiction history that caused a rejection from the new friends when they come to know about it and this in effect made the recovering addicts have a low self-confidence. Most of them also confessed that they did not know how to make new friends. Many programs have organized social activities for treated clients to socialize with ex-addicts and to help each other. All of these efforts are paramount to the building of positive social capital among treated addicts. More should be done to expand existing strategies by developing and innovating new programs and activities, so that more social capital can be generated for use among treated clients.

The influence of mass media and no place to go after being released from the rehab center are also the reasons why the participants relapsed. The stories presented in the mass media reminded them of their life stories. This situation caused them to feel sad and depressed, thus pressuring them to take alcohol and liquor to relieve the pain. Most participants also have no direction after their acquittal. Although some of them have families, the majority refused to bother their families, and felt discomfort to live with them. This situation caused them to lose their way and return to their old friends.

\section{Conclusion and Future Direction}

This research has expanded the literature on the investigation of the risk factors of relapse among drug addicts in the east coast of Malaysia. The findings of this study revealed that the relapse of drug abuse could happen because of internal and external factors. Internal factors include post-acute withdrawal syndrome, while influential external factors include the environment and friends. The major events in life that could be protective factors include family support, and following anti-drug programs. Such major events can initiate and increase self-awareness and be a factor of protective drug abuse. Going forward, the results of this study are useful especially in recognising high-risk factors that lead to drug use and relapse. This will assist therapists in designing appropriate interventions for relapse prevention. The findings also allow health professionals to consider the root causes of relapses and risk factors in the recovery process of drug abuse to support relapse prevention in drug abuse. Furthermore, a possible sources of bias and limitations of the study was that it relied on retrospective self-reports to determine factors in the relapse process. Personal subjectivity and insight into their recovery process often restrict the reliability of the data disclosed. A final limitation of present study was number of respondents and at the same time reaching saturation point. However, a large sample size risks having repetitive data. Future studies need to address these issue by some well-established methods such as using triangulation or grounded study in their research. In conclusion, as we strive to confront the major health challenges of drug overdoses and now the rising infections of COVID-19, we encourage researchers to request supplements that will allow them to obtain data on the risks of COVID19 in individuals experiencing substance use disorders. 


\section{References}

Asensio, S., Hernandez-Rabaza, V., \& Semper, J. V. O. (2020). What Is the "Trigger" of Addiction? Frontiers in Behavioral Neuroscience, 14, 54-78.

Baharudin, D. F., Amat, M. A. C., Jailani, M. R. M., \& Sumari, M. (2011). The concept of forgiveness as a tool in counseling intervention for well-being enhancement. PERKAMA International Convention.

Bandura, A. (1997). Self-efficacy: The exercise of control. Macmillan.

Brown, S. A., D'Amico, E. J., McCarthy, D. M., \& Tapert, S. F. (2001). Four-year outcomes from adolescent alcohol and drug treatment. Journal of Studies on Alcohol, 62(3), 381-388.

Chen, L., Li, N., Ge, S., Lozano, A. M., Lee, D. J., Yang, C., Li, L., Bai, Q., Lu, H., \& Wang, J. (2019). Long-term results after deep brain stimulation of nucleus accumbens and the anterior limb of the internal capsule for preventing heroin relapse: An open-label pilot study. Brain Stimulation, 12(1), 175-183.

Chie, Q. T., Tam, C. L., Bonn, G., Wong, C. P., Dang, H. M., \& Khairuddin, R. (2015). Drug abuse, relapse, and prevention education in Malaysia: Perspective of university students through a mixed methods approach. Frontiers in Psychiatry, 6, 1-13.

Creswell, J. W., \& Creswell, J. D. (2017). Research design: Qualitative, quantitative, and mixed methods approaches. Sage publications.

Crouch, M., \& McKenzie, H. (2006). The logic of small samples in interview-based qualitative research. Social Science Information, 45(4), 483-499.

Darwish, S., \& Abdeldayem, M. M. (2019). Risk Management and Business Ethics: Relations and Impacts in the GCC. International Journal of Civil Engineering and Technology, 10(10), 489-504.

Dong, Y., Taylor, J. R., Wolf, M. E., \& Shaham, Y. (2017). Circuit and synaptic plasticity mechanisms of drug relapse. Journal of Neuroscience, 37(45), 10867-10876.

Emrick, C. D., \& Beresford, T. P. (2016). Contemporary negative assessments of alcoholics anonymous: A response. Alcoholism Treatment Quarterly, 34(4), 463-471.

Etikan, I., \& Bala, K. (2017). Sampling and sampling methods. Biometrics \& Biostatistics International Journal, 5(6), 215-217.

Fraser, S., \& Moore, D. (2008). Dazzled by unity? Order and chaos in public discourse on illicit drug use. Social Science \& Medicine, 66(3), 740-752.

Galletta, A. (2013). Mastering the semi-structured interview and beyond: From research design to analysis and publication (Vol. 18). NYU press.

Goodson, I. F., \& Sikes, P. J. (2001). Life history research in educational settings: Learning from lives. Open University Press.

Habibi, R., Nasrabadi, A. N., Hamedan, M. S., \& Moqadam, A. S. (2016). The effects of familycentered problem-solving education on relapse rate, self efficacy and self esteem among substance abusers. International Journal of High Risk Behaviors \& Addiction, $5(1), 1-16$.

Ibrahim, F., \& Kumar, N. (2009). Factors Effecting Drug Relapse in Malaysia: An Empirical Evidence. Asian Social Science, 5(12), 37-44.

Ibrahim, F., Talib, M. A., Samah, B. A., \& Sabran, M. S. (2008). Family Support and Tendency of Relapse among Drug Addicts in Malaysia. Journal of Social Policy and Society, 5, 181-193.

Jaafar, J. L. S. (2002). Psikologi Remaja [adolescent psychology]. Pearson Malaysia. 
Lian, T. C., \& Chu, F. Y. (2013). A Qualitative Study on Drug Abuse Relapse In Malaysia: Contributory Factors And Treatment Effectiveness. International Journal of Collaborative Research on Internal Medicine \& Public Health, 5(4), 217-232.

Liu, J., Zhao, S., Chen, X., Falk, E., \& Albarracin, D. (2017). The influence of peer behavior as a function of social and cultural closeness: A meta-analysis of normative influence on adolescent smoking initiation and continuation. Psychological Bulletin, 143(10), 1082.

Mahoney, J. L., \& Stattin, H. (2000). Leisure activities and adolescent antisocial behavior: The role of structure and social context. Journal of Adolescence, 23(2), 113-127.

Mericle, A. A., Miles, J., \& Way, F. (2015). Recovery residences and providing safe and supportive housing for individuals overcoming addiction. Journal of Drug Issues, 45(4), 368-384.

Merikangas, K. R., \& Stevens, D. E. (2005). Substances abuse among women: Familial factors and comorbidity. http://www.drugabuse.gov/PDF/DARHW/245270_Merikangas.pdf

Merriam, S. B., \& Grenier, R. S. (2019). Qualitative research in practice: Examples for discussion and analysis (2nd ed.). John Wiley \& Sons.

Merriam, S. B., \& Tisdell, E. J. (2015). Qualitative research: A guide to design and implementation. John Wiley \& Sons.

Rahman, M. M., Rahaman, M. M., Hamadani, J. D., Mustafa, K., \& Islam, S. M. (2016). Psychosocial factors associated with relapse to drug addiction in Bangladesh. Journal of Substance Use, 21(6), 627-630.

Rami, A. M., Abdullah, R., \& Ariffin, W. J. (2018). Strengthening social capital: Local leader's strategy toward developing rural community. International Journal of Academic Research in Business and Social Sciences, 8(1), 765-774.

Sabouripour, F., \& Roslan, S. (2015). Resilience, optimism and social support among international students. Asian Social Science, 11(15), 159-170.

Shariff, A. A. M., Azhar, A., Rajamanickam, R., Manap, N. A., Hussein, S. M., Said, M. H. M., Ab Halim, A. H., \& Markom, R. (2019). Analysis on Admissibility of DNA Evidence in Malaysian Syariah Courts. Academic Journal of Interdisciplinary Studies, 8(4), 159-159.

Sinha, R., Shaham, Y., \& Heilig, M. (2011). Translational and reverse translational research on the role of stress in drug craving and relapse. Psychopharmacology, 218(1), 69-82.

Song, S., Zilverstand, A., Gui, W., Li, H., \& Zhou, X. (2019). Effects of single-session versus multi-session non-invasive brain stimulation on craving and consumption in individuals with drug addiction, eating disorders or obesity: A meta-analysis. Brain Stimulation, 12(3), 606-618.

Stein, M. D., Conti, M. T., Kenney, S., Anderson, B. J., Flori, J. N., Risi, M. M., \& Bailey, G. L. (2017). Adverse childhood experience effects on opioid use initiation, injection drug use, and overdose among persons with opioid use disorder. Drug and Alcohol Dependence, 179, 325-329.

Stewart, J. L., May, A. C., Aupperle, R. L., \& Bodurka, J. (2019). Forging neuroimaging targets for recovery in opioid use disorder. Frontiers in Psychiatry, 10, 117-131.

Taib, M., \& Khairi, R. M. (2000). Pola-pola komunikasi kekeluargaan: Kajian di kalangan keluarga penagih dan bukan penagih di Negeri Kedah. Penyelidikan Sekolah Pembamgunan Social.

The National Anti-Drugs Agency. (2015). Drug Report January - December 2015. Ministry of Home Security. 
Van Delden, A. J. (2017). Adolescent substance use trajectories in relation to internalizing problems in young adulthood: The role of friendship quality [Master's Thesis]. Universiteit Utrecht.

Volkow, N. D., Wang, G.-J., Fowler, J. S., \& Tomasi, D. (2012). Addiction circuitry in the human brain. Annual Review of Pharmacology and Toxicology, 52, 321-336.

Williams, R. J., \& Chang, S. Y. (2000). A comprehensive and comparative review of adolescent substance abuse treatment outcome. Clinical Psychology: Science and Practice, 7(2), 138-166.

Witkiewitz, K., \& Marlatt, G. A. (2004). Relapse prevention for alcohol and drug problems: That was Zen, this is Tao. American Psychologist, 59(4), 224-235.

Ibrahim, F., \& Kumar, N. (2009). The influence of community on relapse addiction to drug use: Evidence from Malaysia. European Journal of Social Sciences, 11(3), 471-476. Retrieved from

Ibrahim, F., Kumar, N., \& Samah, B. A. (2011). Self efficacy and relapsed addiction tendency: An empirical study. Social Sciences, 6(4), 277-282. doi:10.3923/sscience.2011.277.282

Khasmohammadi, M., Ehsaei, G., S., Vanderplasschen, W., Dortaj, F., Farahbakhsh, K., Afshar, K. H., . . . Hormozi, A. K. (2020). The impact of addictive behaviors on adolescents psychological well-being: The mediating effect of perceived peer support. Journal of Genetic Psychology, 181(2-3), 39-53. doi:10.1080/00221325.2019.1700896 